\title{
Prevalence of the use of light technologies by the nursing staff of a state hospital
}

\author{
Prevalência da utilização de tecnologias leves pela equipe de enfermagem de um hospital \\ estadual
}

Pabliane Matias Lordelo Marinho ${ }^{1}$, Thialla Andrade Carvalho ${ }^{1}$, Maria Cláudia Tavares de Mattos ${ }^{1}$, Eliana Ofélia Llapa-Rodríguez ${ }^{1}$, Maria Pontes de Aguiar Campos ${ }^{1}$

Objective: to describe the prevalence of the use of light technologies by the nursing team of a state hospital. Methods: cross-sectional and observational study. The sample consisted of 19 Nurses and 67 Nursing Technicians. The data were collected through direct simple observation using a validated instrument. Chi-square was used to compare the use of light technologies between the nursing categories. Results: there was prevalence of nursing technicians, females, with no partner and with an employment relationship. In the "Bonding" dimension, the interventions presence and security enhancement prevailed for nursing technicians and nurses, respectively. In the "Welcoming" dimension, surveillance and security were the most used by both categories. Conclusion: evaluation of the prevalence of light technologies showed that the dimensions "Welcoming" and "Bonding" were the most used by the nursing team and that nurses use them more often than the Nursing Technicians in the studied unit.

Descriptors: Biomedical Technology; Critical Care Nursing; Intensive Care Units.

Objetivo: descrever a prevalência da utilização de tecnologias leves pela equipe de Enfermagem de um hospital estadual. Métodos: estudo transversal e de natureza observacional. A amostra foi composta por 19 Enfermeiros e 67 Técnicos de Enfermagem. Os dados foram coletados por meio de observação simples direta, utilizando instrumento validado. Utilizou-se qui-quadrado para comparação do uso de tecnologias leves entre as categorias de enfermagem. Resultados: prevaleceu técnico de enfermagem, do sexo feminino, sem companheiro e com um vínculo empregatício. Na dimensão "Vínculo" prevaleceram as intervenções presença para os técnicos e aumento da segurança para enfermeiros. Na dimensão "Acolhimento", supervisão e segurança foram as mais utilizadas pelas duas categorias. Conclusão: a avaliação da prevalência das tecnologias leves mostrou que as dimensões mais utilizadas pela equipe de enfermagem foram "Acolhimento" e "Vínculo" e que os enfermeiros utilizam-nas mais que os Técnicos de Enfermagem na unidade do estudo.

Descritores: Tecnologia em Saúde; Enfermagem de Cuidados Críticos; Unidade de Terapia Intensiva.

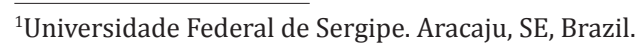

Corresponding author: Thialla Andrade Carvalho

Rua Maye Bell Taylor, № 151, Bairro Luzia. CEP: 49045030. Aracaju, SE, Brazil. E-mail: thiallaba@hotmail.com 


\section{Introduction}

There are several technologies used for the development of work in health institutions. These can be classified into: hard technologies, which includes technological equipment such as machines, devices and organizational structures; light-hard technologies, which includes the knowledge that guide health work; and light technologies, which are relationships based on bonding, autonomy, welcoming and management of the work process ${ }^{(1-2)}$.

Light technology can be understood as the construction of an optimized relationship for the provision of health care, established between the professional and/or team and the patient. Thus, the formation of bond between the actors in the provision of health care is encouraged. Therefore, it broadens the recognition of individual and singular needs and, at the same time, promotes autonomy for decision making. In addition, it produces collective management spaces and active participation of all those involved in the care process - professional/health team, patient and managers $^{(1-2)}$.

The use of light technologies in a hospital environment is mentioned in the National Humanization Policy as essential for the recovery of universal access, equity and comprehensive care to the individual and to promote a humanized care. In this way, the requalification of the relationships between professional and/or health team and patients, based on values such as respect for singularities and defense of users' rights, is extremely necessary and relevant ${ }^{(3)}$.

Another parallel can be made with assumptions of some nursing theorists who, although following distinct theoretical-philosophical references, are premised on the production of reciprocity and interaction and environmental relations, indispensable to an effective care, recovery of autonomy and citizenship $^{(4-5)}$.

There are few papers in the literature mentioning or using relationship technologies or light technologies in nursing. This fact mat be due to the difficulty of professionals in defining what these technologies are and in recognizing them as technological resources. A study that evaluated the use of technologies in nursing showed that only $9.0 \%$ of the articles addressed light technologies and 2.9\% addressed light and light-hard technologies ${ }^{(6)}$.

Likewise, it was stated that the use of nursing technologies can have a $58.8 \%$ impact on the strengthening and quality of patient care in nursing. Therefore, light technology, emanating from the relationship with the nursing team, is capable of providing planning based on patients' individualities and real needs. Thus, a singular, reflexive, effective and safe care is generated $^{(6)}$.

Given the above and given the importance of this theme for the development of a quality nursing care, this study aims to describe the prevalence of the use of light technologies by the nursing team of a state hospital.

\section{Methods}

This is a cross-sectional and observational study. The research environment was the Intensive Care Unit of a large Health Care Institution of the State Health Network of Sergipe, Brazil.

The sample consisted of 86 workers (19 nurses and 67 nursing technicians/assistants), who correspond to $77.5 \%$ of the nursing staff professionals (111). The selection was made by non-probabilistic sampling by quota, stratified by professional category and obtained assuming a 5.0\% sample error and a $95.0 \%$ confidence interval. Inclusion criterion of this research was developing care activity in the Intensive Care Unit. Exclusion criteria were professionals' absence due to vacations or leaves in the period of data collection.

Data were collected from March 1 to 31, 2015 by the research team and by nursing undergraduates from the Federal University of Sergipe, who had received training. The collection instrument was developed based on the psychometric methodology, the- 
oretical reference of light technologies of Mehry and Feuerweker and on the National Humanization Policy of the Unified Health System.

Between December 2014 and January 2015, the instrument was validated by six judges, selected by criteria adapted from Fering, who analyzed six criteria: appearance, clarity/comprehension, content, efficiency/consistency, objectivity and validity of the proposed model.

The first part of the instrument is related to the characterization of the sample in terms of bio-socio-demographic (age, sex, marital status, schooling) and professional aspects (position, length of time in the sector, weekly working hours, number of employment relationships and satisfaction in working in the sector). The second part investigated the use of light technologies by the nursing team, based on four dimensions identified in the concept of light technology of the selected theoretical framework.

In order to adapt the light technology to nursing practice, the Nursing Interventions Classification (NIC) was used. Thus, a search in NIC was conducted and 19 nursing interventions with definitions and activities that were more similar to the points identified in the selected referential were selected. Then, these were grouped into the corresponding dimensions: Bonding, Autonomy, Welcoming and Management.

The guideline of the first dimension is the construction of bond between the person and the professional. This relationship requires an affective and moral connection and promotes learning about caring. Thus, the nursing interventions selected were: Active Listening (4920); Touch (5460); Complex Relationship Building (5000); Security Enhancement (5380); and Presence (5340).

In the second dimension, the guideline establishes that the process of health production is complete when people become subjects capable of deciding about their care and, together with health professionals, are able to build working rules for themselves and all. Self-Care Assistance (1800) was chosen; Assertiveness Training (4340); Emotional support (5270);
Self-awareness Enhancement (5390); and Values Clarification (5480) were chosen in the NIC.

Welcoming the user, since his/her arrival, becoming responsible for him/her and opening of spaces for listening and speaking in care and assistance relationships are the guidelines of welcoming practices in services, which were applied to the third dimension. For this study, the following nursing interventions were chosen: Surveillance: Safety (6654); Shift Report (8140); Case Management (7320); Admission Care (7310); Visitation Facilitation (7560).

In the last dimension, the way of managing work processes and the analysis of information and decision making is built by collective spaces, with involvement of all entities in the health producing units. Thus, the following interventions were selected: Critical Path Development (7640); Decision-Making Support (7560); Patient Rights Protection (7460); and Health Education Enhancement (5515).

Direct and simple observations were performed, in which professionals were analyzed during provision of care. Each pre-selected nursing intervention in which three activities were performed by the observed professional was equivalent to "yes", being registered in the instrument. On average, three hours of observations were carried out from Monday to Friday during the three work shifts.

The variables selected for this study were: the dependent variable corresponding to the application of light technologies and the independent variables concerning the bio-socio-demographic and professional attributes.

Data were tabulated in the Epi-info 7 program and analyzed using BioEstat software for Windows ${ }^{\circledR}$ version 5.3. In order to analyze the categorical variables, a simple distribution frequency was used. The Kolmorogov-Smirnov test was performed to evaluate the normality distribution regarding the use of light technology and the Chi-square test $\left(\chi^{2}\right)$ and/or Fisher's Exact test was used to compare the use of light technologies between the nursing categories. In order to analyze the quantitative variable "number of 
nursing interventions", the central tendency measure - median - was used as the sample did not present a normal distribution.

The study complied with the formal requirements contained in the national and international regulatory standards for research involving human beings.

\section{Results}

The results, shown in Table 1, evidenced prevalence of females (76.7\%). There was higher presence of people without partner and nursing technicians with higher education.

The relationship between number of employment relationships and workload showed that, although most professionals had only one employment relationship, the number of professionals with a weekly workload exceeding 60 hours per week was significant (46.5\%). Another highlight is the high percentage of positive answers (90.7\%) about satisfaction in working in the Intensive Care Unit.

Regarding the light technologies (Table 2) used by the nursing team, the most prevalent dimensions were "Welcoming" (52.3\%) and "Bonding" (48.8\%). Regarding the professional category, the dimensions "Welcoming" (68.4\%) and "Management" (52.6\%) prevailed for nurses, while for nursing technicians, "Bonding" (47.8\%) and "Welcoming" (47.8\%) prevailed.

In the "Bonding" dimension, the most used nursing interventions were Security Enhancement (5380) for both categories, followed by Touch (5460) for nurses and Presence (5340) for nursing technicians.

The most prevalent nursing intervention in the "Autonomy" dimension was Self-Care Assistance (1800), occurring in the same way for both categories. It is observed that this intervention was the only one with prevalence in the nursing technician category. For the nursing team, the least prevalent was Values Clarification (5480). It should be emphasized that this was the least observed intervention in nursing care practice.
Table 1 - Distribution of the sample according to bio-socio-demographic and professional variables $(\mathrm{n}=86)$

\begin{tabular}{|c|c|}
\hline Variable & n (\%) \\
\hline \multicolumn{2}{|c|}{ Age, mean $/$ standard deviation $=34.20 / 6.18$} \\
\hline $25-34$ & $52(60.5)$ \\
\hline $35-44$ & $27(31.4)$ \\
\hline $45-54$ & $7(8.1)$ \\
\hline \multicolumn{2}{|l|}{ Gender } \\
\hline Male & $20(23.3)$ \\
\hline Female & $66(76.7)$ \\
\hline \multicolumn{2}{|l|}{ Marital status } \\
\hline With partner & $31(36.0)$ \\
\hline Without partner & $55(64.0)$ \\
\hline \multicolumn{2}{|l|}{ Position } \\
\hline Nurse & $19(22.1)$ \\
\hline Nursing technician & $67(77.9)$ \\
\hline \multicolumn{2}{|l|}{ Schooling } \\
\hline High school & $28(32.5)$ \\
\hline Higher education & $43(50.0)$ \\
\hline Higher education with graduation & $15(17.5)$ \\
\hline \multicolumn{2}{|c|}{ Length of time in the sector, mean $/$ standard deviation $=3.68 / 2.03$} \\
\hline \multicolumn{2}{|l|}{ Work shift } \\
\hline Morning & 15 (17.5) \\
\hline Afternoon & $21(24.4)$ \\
\hline Evening & $50(58.1)$ \\
\hline \multicolumn{2}{|l|}{ Number of employment relationships } \\
\hline 1 & $54(62.8)$ \\
\hline 2 & $32(37.2)$ \\
\hline \multicolumn{2}{|l|}{ Weekly workload (hours) } \\
\hline $30-36$ & $41(47.7)$ \\
\hline $40-44$ & $5(5.8)$ \\
\hline$>60$ & $40(46.5)$ \\
\hline \multicolumn{2}{|c|}{ Satisfaction about working in Intensive Care Unit } \\
\hline No & $8(9.3)$ \\
\hline Yes & $78(90.7)$ \\
\hline
\end{tabular}

In the "Welcoming" dimension, the nursing intervention Surveillance: Safety (6654) was the most prevalent for nurses and nursing technicians, being used by $94.7 \%$ and $86.6 \%$ of these, respectively. It is worth noting the finding regarding the nursing intervention Visitation Facilitation (7560), with only 2.3\%, 
and the lamentable fact that this intervention is the second least practiced by nurses.

When the "Management" dimension was evaluated, there was a significantly higher percentage of use among nurses (52.6\%) when compared to nursing technicians (28.3\%). Among the nursing interventions of this dimension, Patient Rights Protection (7460) was the most prevalent for both nursing categories, being more used by nurses.
Of the 19 nursing interventions applied by the team, only three did not present a statistically significant difference between the professional categories: Visitation Facilitation (7560), Self-Care Assistance (1800) and Assertiveness Training (4340). In this stu$\mathrm{dy}$, the median value was seven nursing interventions per professional category. Thus, $74.0 \%$ of nurses and $51.0 \%$ of nursing technicians presented performance above the median in the use of light technologies.

Table 2 - Distribution of the prevalence of use of light technologies according to the dimensions Bonding, Autonomy, Welcoming and Management by professional category

\begin{tabular}{|c|c|c|c|c|}
\hline \multirow{2}{*}{ Nursing interventions according to dimension } & Use & p-value & Nurses $(n=19)$ & Nursing technicians $(n=67)$ \\
\hline & n (\%) & & n(\%) & n(\%) \\
\hline Bonding & $42(48.8)$ & & $10(52.6)$ & $32(47.8)$ \\
\hline Active Listening (4920) & $30(34.9)$ & $<0.000$ & $9(47.4)$ & $21(31.3)$ \\
\hline Touch (5460) & $41(47.7)$ & $<0.000$ & $12(63.2)$ & $29(43.3)$ \\
\hline Complex Relationship Building (5000) & $23(26.7)$ & $<0.000$ & $5(26.3)$ & $18(26.9)$ \\
\hline Security Enhancement (5380) & $61(70.9)$ & $<0.000$ & $15(78.9)$ & $46(68.7)$ \\
\hline Presence (5340) & $56(65.1)$ & $<0.000$ & $11(57.9)$ & $45(67.2)$ \\
\hline Autonomy & $28(32.5)$ & & $5(26.3)$ & $23(34.3)$ \\
\hline Values Clarification (5480) & $9(10.5)$ & 0.004 & $1(5.3)$ & $8(11.9)$ \\
\hline Self-care Assistance (1800) & $75(87.2)$ & 0.526 & $12(63.2)$ & $63(94.0)$ \\
\hline Assertiveness Training (4340) & $11(12.8)$ & 0.526 & $2(10.5)$ & $9(13.4)$ \\
\hline Self-Awareness Enhancement (5390) & $16(18.6)$ & 0.001 & $1(5.3)$ & $15(22.4)$ \\
\hline Emotional Support (5270) & $30(34.9)$ & 0.001 & $8(42.1)$ & $22(32.8)$ \\
\hline Welcoming & $45(52.3)$ & & $13(68.4)$ & $32(47.8)$ \\
\hline Admission Care (7310) & $40(46.5)$ & 0.000 & $12(63.2)$ & $28(41.8)$ \\
\hline Case Management (7320) & $44(51.2)$ & $<0.000$ & $17(89.5)$ & $27(40.3)$ \\
\hline Surveillance: safety (6654) & $76(88.4)$ & 0.019 & $18(94.7)$ & $58(86.6)$ \\
\hline Shift Report (8140) & $63(73.3)$ & 0.000 & $17(89.5)$ & $46(68.7)$ \\
\hline Visitation Facilitation (7560) & $2(2.3)$ & 0.501 & $2(10.5)$ & $0(0.0)$ \\
\hline Management & $29(33.7)$ & & $10(52.6)$ & $19(28.3)$ \\
\hline Critical Path Development (7640) & $35(40.7)$ & $<0.000$ & $13(68.4)$ & $22(32.8)$ \\
\hline Decision-Making Support (7560) & $25(29.1)$ & $<0.000$ & $9(47.4)$ & $16(23.9)$ \\
\hline Health Education Enhancement (5515) & $13(15.1)$ & 0.000 & $8(42.1)$ & $5(7.5)$ \\
\hline Patient Rights Protection (7460) & $44(51.2)$ & 0.001 & $13(68.4)$ & $31(46.3)$ \\
\hline
\end{tabular}




\section{Discussion}

A limitation of this study was having conducted the research with professionals from a single health institution, thus portraying a local reality. The method used for data collection was also a limitation, as simple observation raises the subjective and partial interpretation of the studied phenomenon and the presence of the researcher can provoke alterations in the behavior of the observed participants.

Regarding the characterization of the sample, the prevalence of females corroborates a research of the Federal Nursing Council ${ }^{(7)}$, which also had similar result on the higher education of nursing technicians. This may be explained by the growing number of nursing colleges and by increased access to federal government grants through a student funding program ${ }^{(7-8)}$. This fact, however, did not approximate the results regarding the use of light technologies when the performance by category was evaluated.

Most of the professionals referred only to one employment relationship, but they had a long working day, associated with the fact that many of them worked extra hours in the same unit. This is a worrying result, since long journeys are pointed out in the literature as one of the main factors that trigger stress in the professional, thus compromising the quality of nursing $\operatorname{care}^{(9)}$.

Almost all the participants of the study reported satisfaction about working in the Intensive Care Unit under study. This is a positive result, since satisfaction has influence in the care provided by the nursing team. This refers to a sum of internal and external variables that influence motivation for developing care activities and productivity, regardless of technical-scientific training, in addition to being intrinsically linked to autonomy to perform labor activities and quality of life at work ${ }^{(4,10)}$.

As for light technologies, the prevalence of the dimensions "Welcoming" and "Bonding" demonstrate how much the nursing team is aware on the importance of the humanization process. This fact implies the involvement of health professionals and the use of relationships as technology, building a construction among the subjects and providing a foundation for the meeting of mutual needs ${ }^{(5-6)}$. However, in view of the obtained results, it is recommended the requalification of the relations between professionals and patients with the re-evaluation in professional training ${ }^{(1,3,5)}$.

Within these dimensions, the most used nursing interventions for both categories were those related to the control of risk factors for patient safety and that confirm relevant aspects of care ${ }^{(4,5,11)}$ adopted by the nursing team working in this unit. The low percentage of use observed in the nursing intervention related to the establishment of therapeutic relationship can be justified by the profile of the patients hospitalized in this unit, by the predominance of interaction with the hard technologies available and by the biomedical model in the Intensive Care Unit, which hinders insight production ${ }^{(11)}$.

Similarly, the same explanation is considered for the lower prevalence of the autonomy intervention. However, a study confirms changes in the physiological responses when auditory and tactile stimuli are performed ${ }^{(12)}$, a fact little observed in the Intensive Care Unit. Therefore, it is paramount to expand nursing interventions regarding assertiveness, self-perception, emotional support and self-care for the recovery of equity and comprehensive care, which is a challenge of the National Humanization Policy ${ }^{(3)}$.

The feasibility of access of relatives and companions to the Intensive Care Unit is an action performed and guided by nurses; however, this was the least used nursing intervention by the studied team. This is an opposite result to that recommended by the National Humanization Policy guidelines ${ }^{(2)}$, since the approximation of the social network of the patient to the care process is paramount for a comprehensive care, since they are also subjects of health care ci,5-6). $^{(3)}$ 
Humanization in this unit is not an easy task, because it requires individual attitudes against an established biomedical model and a technological system, often not humanizing ${ }^{(6)}$. Another complicating factor is the existence of norms and routines, which are crucial to the organization, and which need to be manageable for the exercise of a humanized care to critical patients, and nurses have responsibility in this process $^{(3,6,13)}$. Visitation should provide effective communication and a therapeutic relationship with the family, thus favoring the understanding of the whole and patient rehabilitation ${ }^{(3,14)}$.

Management of care, with better results among nurses, has confirmed the responsibility for the management of the care provided by this category, in addition to complying with the Civil Code, Consumer Law, and the Professional Ethics Code with respect to the citizen's rights ${ }^{(15-17)}$. In critical units, in addition to developing complex care activities, the nurse must manage care dynamically, leading the team to achieve the best results, client and family satisfaction, and to reduce adverse events related to care ${ }^{(4,10,17)}$.

It should be emphasized that the unit under study carries out the Nursing Process, however, there is no emphasis on light technologies, being predominant the biomedical model based on the resolution of biological problems. The light technologies are confused with the work process itself and nursing care. Therefore, it is emphasized, the need for reevaluation and the insertion of these technologies in the care process $^{(3-4,11)}$. Reformulations are necessary in order to adopt light technologies in this Intensive Care Unit, in view of the positive impact on the care given to the critical patient ${ }^{(6,11,17)}$.

It is highlighted, as contribution of this study, the construction of scientific knowledge related to the light technologies applied by the nursing team in intensive care unit. It also allows professionals and managers of the studied institution to reflect on the use of light technologies and to plan interventions to intensify the use thereof.

\section{Conclusion}

Evaluation of the prevalence of light technologies showed that the most used dimensions by the nursing team were "Welcoming" and "Bonding". Considering the professional category, the dimensions "Welcoming" and "Management" prevailed for nurses, while for nursing technicians, "Bonding" and "Welcoming" prevailed. Nursing interventions, which materialized the light technologies, were predominantly significant.

\section{Collaborations}

Marinho PML contributed to project design, data collection, analysis and interpretation of data and article writing. Carvalho TA contributed to the analysis and interpretation of data and article writing. Mattos MCT and Llapa-Rodríguez EO performed critical review of the intellectual content and approval of the version to be published. Campos MPA contributed to project design, analysis and interpretation of data and critical review of the intellectual content.

\section{References}

1. Merhy EE, Franco TB. Trabalho em saúde. In: Pereira IB, Lima JCF. Dicionário da educação profissional em saúde. Rio de Janeiro: EPSJV; 2008.

2. Merhy EE. Saúde: a cartografia do trabalho vivo. Saúde em Debate. São Paulo: Hucitec; 2002.

3. Ministério da Saúde (BR). Secretaria de Atenção à Saúde. Política Nacional de Humanização da Atenção e da Gestão do SUS [Internet]. 2006 [citado 2017 jan. 13]. Disponível em: http:// bvsms.saude.gov.br/bvs/publicacoes/humaniza_ sus_atencao_basica.pdf

4. Freitas FDS, Silva RN, Araújo FP, Ferreira MA. Environmentand humanization: resumption of nightingale's discourseinthenationalhumanization policy. Esc Anna Nery. 2013; 17(4):654-60. doi: http:// dx.doi.org/10.5935/1414-8145.20130008 
5. Oliveira CN, Nunes EDCA. Caring for family members in the ICU: challenges faced by nurses in the interpersonal praxis of user embracement. Texto Contexto Enferm. 2014; 23(4):954-63. doi: http:// dx.doi.org/10.1590/0104-07072014003590013

6. Pereira CDFD, Pinto DPSR, Tourinho FSV, Santos VEP. Tecnologias em Enfermagem e o impacto na prática assistencial. Rev Bras Inov Tec Saúde [Internet]. 2012 [citado 2016 fev. 26]; 2(04):2937. Disponível em: www.ufrn.emnuvens.com.br/ reb/article/view/333

7. Escola Nacional de Saúde Pública. Conselho Federal de Enfermagem. Perfil da Enfermagem [Internet]. 2012 [citado 2016 set. 18]. Disponível em: http://aenfermagem.com.br/materia/perfilda-enfermagem.

8. Queiroz V. Fundo de Financiamento Estudantil (FIES): uma nova versão do CREDUC. Universidade Soc [Internet]. 2015 [citado 2017 fev. 08]; 24(55):44-57. Disponível em: http:// www.andes.org.br/imprensa/publicacoes/imp-pub-1227849465.pdf

9. Dalri RCMB, Silva LA, Mendes AMOC, Robazzi MLCC. Nurses' workload and its relation with physiological stress reactions. Rev Latino-Am Enfermagem. 2014; 22(6):959-65. doi: http:// dx.doi.org/10.1590/0104-1169.3292.2503

10. Carvalho JF, Martins EPT, Lúcio L, Papandréa PJ. Qualidade de vida no trabalho e fatores motivacionais dos colaboradores nas organizações. Educ Foco. 2013; 7(9):21-31.

11. Terra TCC, Gomes SR. A humanização da assistência em unidade de terapia intensiva para adultos. Reinpec. 2015; 1(1):233-44. doi: http://dx.doi. org/10.20951/2446-6778/v1n1a17
12. Puggina ACG, Silva M JP. Patients with disorders of consciousness: vital, facial and muscular responses to music or messages. Rev Bras Enferm. 2015; 68(1):102-10. doi: http://dx.doi. org/10.1590/0034-7167.2015680114p

13. Silva RS, Pereira Á, Mussi FC. Comfort for a good death: perspective nursing staff's of intensive care. Esc Anna Nery. 2015; 19(1):40-6. doi: http:// dx.doi.org/10.5935/1414-8145.20150006

14. Barth AA, Weigel BD, Dummer CD, Machado KC, Tisott TM. Stressors in the relatives of patients admitted to an intensive care unit. Rev Bras Ter Intensiva. 2016; 28(3):323-9. doi: http://dx.doi. org/10.5935/0103-507X.20160055

15. Soares LG, Reis MR, Leticia Gramazio Soares. Humanização na UTI: dificuldades encontradas para sua implementação uma revisão integrativa. Rev Polidisciplinar Eletr Faculdade Guairacá [Internet]. 2014 [citado 2016 fev 21]; 6(1):70-86. Disponível em: http://www.revistavoos.com.br/ seer/index.php/voos/article/viewArticle/263

16. Conselho Federal de Enfermagem (BR). Resolução COFEN no 311/2007 de 8 de fevereiro de 2007 (BR). Dispõe sobre: Aprova a reformulação do Código de ética dos profissionais de enfermagem [Internet], Rio de Janeiro (RJ). 2007 [citado 10 mar 2016]. Disponível em: http://se.corens. portalcofen.gov.br/codigo-de-etica-resolucaocofen-3112007

17. Balsanelli AP, Cunha ICKO. Nursing leadership in intensive care units and its relationship to the work environment . Rev Latino-Am Enfermagem. 2015; 23(1):106-13. doi: http://dx.doi. org/10.1590/0104-1169.0150.2531 